Вісник Львівського університету. Серія філос.-політолог. студіі. 2020. Випуск 30, с. 91-95

Visnuk of the Lviv University. Series Philos.-Political Studies. Issue 30, p. 91-95

UDC 141.7 (477)

DOI https://doi.org/10.30970/PPS.2020.30.12

\title{
PHILOSOPHICAL RETROSPECTIVE OF THE GENDER ISSUE
}

\author{
Ruslana Mnozhynska \\ Kyiv National University of Technology and Design, \\ Department of Philosophy, Political Science and Ukrainian Studies \\ Nemyrovycha-Danchenko str. 2, 01011, Kyiv, Ukraine
}

Relationships between women and men have always been the subject of attention of philosophers, historians, theologians, sociologists, culturologists, public figures. New worldview systems and the emergence of gender theory are becoming widespread, and gender begins to be declared the subject of personal choice.

The author considers the concept of "gender", revealing its socio-cultural significance and analyzing the development in historical retrospect. The multifaceted nature of the concept of "gender" and the variability of accentuations in its interpretations by different researchers are noted. Considering historically gender issues, the author identifies four gender-role types, which are inherent in both men and women: masculine, feminine, androgenic and undifferentiated.

The study of gender issues originates from ancient thinkers, namely: Plato and Aristotle, who in their work begin to consider the relationship between man and woman both within the family and in society. Each historical epoch gives us a model according to which a man and a woman should interact. The Middle Ages were marked by a dual attitude to gender issues: on the one hand, biblical history, and on the other, medieval society with its norms and ideas, where the basic female characteristics are related to the biological and cultural status of women. The article emphasizes that one of the first in the national Renaissance philosophical thought, who considered this issue was Stanislav Orikhovsky cue. In the works of socio-political and ethical orientation, he asserted first of all the ethics and ideology of humanism, which gives the individual a higher step in the hierarchy of values, puts forward the ideal of its comprehensive and harmonious development. As a Renaissance humanist, Orikhovsky considered women a blessing not only in private life. In her opinion, she can be useful for the common good of the state, if she is, for example, a queen.

It is important to understand that gender issues are historical in nature and constantly evolving. The main purpose of the article is to consider the evolution of the formation of gender issues in the historical and philosophical process.

Key words: man, woman, equality, gender, family, society.

Gender is known to be a concept used to define the sociocultural form of the existence of sexes: man and woman act not as natural definitions, but as sociocultural phenomena. If gender is determined on the basis of bodily, organic and psychophysiological characteristics, then, in contrast, gender is derived from the social, cultural and historical features of human existence. Human behavior in society and how it is perceived in it and defines gender as a social sex. Gender, thus, is one of the ways of social stratification of society, which in combination with such socio-demographic factors as race, nationality, class, it organizes a system of social hierarchy. Since gender is not a natural fact, but a social construct, it presupposes self-awareness and self-determination. At the same time, gender has always been and remains an ambiguous term. In the social sciences, "gender" has acquired a narrower meaning, meaning "social sex", socially determined roles, identities and spheres of activity of men and women, which do not depend on biological gender differences, but on the social organization of society.

(C) R. Mnozhynska, 2020 
Central to gender studies is the problem of social inequality between men and women. Biological sexual differentiation is represented and enshrined in culture through the symbolism of the masculine or feminine (nature, culture, good, evil, and more) associated with the "masculine / masculine" or "feminine / feminine" origins. Thus, there is a symbolic meaning of "feminine" and "masculine", and "masculine" is identified with God, creativity, light, power, activity, rationality, etc. "Feminine" is associated with opposite concepts and phenomena - subordination, weakness, passivity, etc., which, in turn, symbolize femininity - the feminine principle. Instead, gender equality implies the equal acquisition by women and men of socially valuable goods, opportunities, resources and rewards. At the same time, such equality does not mean that men and women become the same, but that their opportunities and life chances are equal [8, p. 5].

To this end, it is proposed to introduce a quota system, which is that women (and the female population makes up at least half of the population in most countries) hold at least some "critical minority" of seats, for example, in parliament. Gender quotas are a legalized level of representation of women and men in government. The quotas are based on the modern concept of equality between women and men. The main idea of gender quotas is to significantly increase the political representation of women, to involve them in the level of political decision-making and to prevent the isolation of women from political life.

The quota system raises a number of serious issues and in some cases provokes strong resistance. Arguments "for" and "against" the use of the quota system are given, quota methods are studied, the most effective ways of applying the quota system are discussed, the practice of countries that use such a system is analyzed. Based on international experience, it should be emphasized that the quota system, for all its positive and constructive characteristics, is not without certain shortcomings that can respond to negative consequences. Hence the conclusion: the quota system can be used only as a temporary measure, until the barriers to women's path to politics are removed [7, p. 14].

However, there are many opponents of gender as a socio-cultural phenomenon, who believe that human biology clearly defines male and female social roles, psychological characteristics, areas of occupation, etc., and the word gender is used as "more modern". The content of the situation does not change even when the authors still recognize gender as a biological fact and gender as a social construct, but the presence of two opposite "genders" (male and female) is perceived as a reflection of two biologically different sexes. It should be noted, however, that women themselves are the most likely to criticize gender, believing that quotas are not a sign of kindness. Here is what Olena Zvarych writes, for example: "Gender is as pragmatic as Hitler he wants women to plow along with fat men. The only difference is that he [the gender] wants us to get high from it, the thrill of involvement. to the great universal cause, the excitement of labor competition, where Pasha Angelina's handkerchief is equal to Stakhanov's caste and no less paid in accounting and at the fair of ambition. "That is, no matter how much humanity progresses in its ideas about humanity, and man, in particular woman, but remains a man, a woman: "You inadvertently submit to this knowledge [that you are a woman], you want to be charming, as long as you have enough intelligence and talent, you wish that thousands of Achaean galleys sailed to you, as to Elena..." [1, p. 20]. "And there is nothing to divide us, to label someone as a leader, and someone as a subordinate, because everything depends on us, on our abilities" - as if summarizes Alena Hrytsenko [1, p. 17].

After all, the theory of gender (social relations of men and women) with its quota system considers only those aspects of life that are not related to love. Gender is a social sphere of life for men and women who are studied separately from each other. And love is an androgyne. Therefore, it is worth knowing our social differences, but understand that they are not in love. So, there 
is nothing to divide love into "feminine" and "masculine", because only false love can be divided, through which alienated feminine nature seems to be reunited with masculine nature, restoring the holistic image of man. That love is "by the ascent of a fallen man to godlikeness" [1, p. 12]. According to the German theosophist Jacob Boehme, who created a coherent mystical doctrine, "androgyne" was the original state of human identity, and only the fall divided the world into two sexes [4, p. 21]. If there were no fall, we would enjoy the fullness of an undivided being. After all, the First Adam was a man and a woman at the same time. And only the fall led to the appearance of Adam and Eve. Thus appeared the division of humanity into men and women - biological sex. However, the fall, which happened once, did not end. The fall continues. This is manifested in the fact that there is a further differentiation of the human race on the basis of sex [4, p. 7].

An example of the extreme manifestation of the protogender approach can be considered, in particular, a brochure with 12 commandments to the revolutionary proletariat, published in the 1920s. in Leningrad, the ninth commandment of which commanded: "Sexual selection must be built on the lines of class revolutionary-proletarian expediency. Elements of flirtation, courtship, coquetry, and other methods of special sexual conquest must not be introduced into amorous relations". The 12th commandment was no less formidable: The class, in the interests of revolutionary expediency, has the right to interfere in the sexual life of its members; the sexual must obey the class in everything, without interfering with the latter, serving it in everything [6, p. 11].

Despite the fact that gender and gender relations began to be actively discussed only a few decades ago, this problem is long-standing. In different ways, the relationship between men and women in biblical times, in ancient times, the Middle Ages and the Renaissance, but without quotas, women were able to sometimes occupy the highest levels of power, but in all spheres of spiritual life. I. The list of names of prominent women who have gained world fame would take up too much space. Ukrainian humanists did not stand aside from this question, it is interesting to cover the "gender" views of Stanislav Orikhovsky (1513-1566) - a prominent Ukrainian philosopher, historian, publicist, polemicist and orator of the first half of the XVI century. Who was perhaps the most prominent figure in the Ukrainian and Polish culture of the Renaissance. Thus, he affirmed, first of all, the ethics and ideology of humanism, which assigns the individual the highest step in the hierarchy of values, puts forward the ideal of its comprehensive and harmonious development. At the same time, in his works he paid considerable attention to the ancient ethical virtues, which concerned the moral improvement of the human individual; as well as the religious culture of the Middle Ages, where the problems of the inner mental life of man, freedom of will and divine destiny, the choice between good / good and $\sin$ / evil come to the fore. Considering certain ethical categories, he filled them with concrete meaning based on the real situation in his life, in particular, related to marriage, which contradicted the canon of the Catholic Church - celibacy. He wrote a number of journalistic works, where he branded, in particular, the law of the Catholic Church on celibacy (celibacy), substantiates the naturalness of marriage and, at the same time, utters a real hymn to a woman. First of all, these are such works as "The Law on Celibacy" and "Letter to the Pope", which were repeatedly published in Western Europe during the author's lifetime. These works testify to the negative attitude of their author to asceticism. Instead, they have a noticeable tendency to rehabilitate the bodily nature of man - and women, in particular [3, p. 106].

One of the greatest causes of evil at that time for Orikhovsky was the Catholic Church's law on celibacy. The thinker claimed that this was the reason for the spread of great corruption and lust of the Catholic clergy, and not the guardian of shyness and virtue, and therefore it is avoided by all, like the plague. Considering this law immoral, because celibacy led to debauchery, Orikhovsky equated the life of the Catholic clergy with Sodom and Gomorrah, from which his wife saved him. After all, it was thanks to marriage that he "freed himself from the excessive 
and shameful dirt of Roman prostitutes and began to lead a virtuous life" [3, p. 161]. Orikhovsky is proud that there is no shameful celibacy in his paternal faith, which encourages Catholic priests to lead a shameful life without wives. It was celibacy, in his opinion, that contributed to debauchery, as the absence of his own wife was compensated by casual extramarital affairs. Therefore, the thinker writes, celibacy is not observed by "Greeks, Alexandrians, Antiochians, Germans and my Rusyns [3, p. 28].

Orikhovsky was well aware of the arguments of the Catholic hierarchs, who introduced celibacy, referring in particular to the passage in the Book of Genesis, which speaks of the secondary and sinfulness of women. In particular, the fact that Adam and Eve lived in a state of innocence in the garden of Eden, where they were allowed to eat the fruit of any tree, except the fruit of the "tree of the knowledge of good and evil" [3, p. 2, 17]. Tempted by the serpent, Eve tasted the forbidden fruit and honored Adam with it. By doing this act of disobedience, they realized their guilt and sinfulness and became like gods who knew the difference between good and evil.

In the Middle Ages and the Middle Ages, women did not have an equal position in society compared to men. And only the humanists of the Renaissance loudly declared their equality. Let us recall, for example, Erasmus of Rotterdam, who defended the legal equality of women in society, in particular the right to education, advocated harmony in family life, condemned prostitution, considering marriage the best form of relationship between men and women, opposed unequal marriages [5, p. 266-267, 272]. At the same time, the reader may be surprised to read the following passage about women: "It seems that Plato still doubted which creatures to include a woman - intelligent or unreasonable. By this he meant that stupidity is a characteristic feature of a woman. sex. That is why even intelligent women willingly pretend to be stupid. Thus, a woman's mind is unnatural and fits no more than a cow's saddle" [3, p. 28]. First, Plato has nothing like this. On the contrary, he believed that women had the same mental abilities as men. And secondly, we must not forget that these words sound from the lips of Stupidity. Ukrainian humanists of the period in question also defended women's rights. In particular, Orikhovsky stated that a woman has the right to even take part "together with her husband in the management of state affairs" [3, p. 272]. This tradition, by the way, was continued by Ukrainian thinkers and later, in particular, Ivan Dombrovsky, in his poem "Dnieper Stones", argued that women have the same virtues as men, leads a whole gallery of heroic women. images of different peoples, especially the glorious Kyivan Princess Olga. And then he calls Semiramids, Tomiris, Penthesilea, Celtic Joanna (Jeanne d'Arc), Libushe - Marcomanni, Polish Wanda [3, p. 106]. Not only men but also women enjoyed individual freedoms in Ukraine and later.

So far, we have considered the basic virtues of women, thanks to which the latter, with great desire and without gender quotas, reached high levels in the social hierarchy, not inferior to men. And if we take into account that in their arsenal there was also such a powerful weapon as beauty (beauty, charm-ness), which no knight could resist, then the question arises: who enslaves whom? Erasmus of Rotterdam also thought about this, writing: "Take at least the external beauty, her women are rightly valued above all in the world and with its help tyrants even tyrants" [5, p. 28].

Finally, I would like to emphasize once again that the problem of gender is as old as the world. It was thought of in ancient times. Proof of this is the poem of the ancient Greek poet of the VII century. B.C. Anacreon called "The Power of Woman".

Thus, women do not need quotas, which aim to legitimize the level of representation of women and men in government, the allocation of a certain number of seats, for example, in the government or parliament. Nature is a caring and predictable mother. She cared about both biological equality between men and women and gender equality. The main thing is not to rape nature, but to listen to it and live in harmony with it. 


\title{
References
}

1. Оріховський Станіслав. Твори. Перекл. Володимира Литвинова. Київ, Дніпро, 2004. 170 с.

2. Українські гуманісти епохи Відродження (Антологія): У 2 т. Упоряд / перекл. 3 лат. В. Литвинов та ін. Київ, 1995. 200 с.

3. Литвинов Володимир. Ренесансний гуманізм в Україні (Ідеї гуманізму епохи Відродження в українській філософії XV - початку XVII століття). Київ, 2000. 175 с.

4. Беме Якоб. Аврора, или Утренняя заря в восхождении. Москва, 1914. 117 с.

5. Роттердамський Еразм. Похвала Глупоті. Домашні бесіди / Перекл. 3 латини В. Литвинова, Й. Кобова. Київ : Основи, 1993. 319 с.

6. Боннэр А. Греческая цивилизация, т. 1. Ростов-на-Дону : Изд-во «Феникс», 1994. Гл. VII. Рабство, положение женщины. 169 с.

7. риценко Алена. Любовь и гендер. URL : http://afield.org.ua.

8. Зварич Олена. Гендер, милий друг. Украӥнська правда. 07.03.2006.

\section{ФІЛОСОФСЬКА РЕТРОСПЕКТИВА ГЕНДЕРНОГО ПИТАННЯ}

\author{
Руслана Множинська \\ Київський національний університет технологій та дизайну, \\ кафедра філософії, політології та українознавства \\ вул. Немировича-Данченка 2, 01011, м. Київ, Україна
}

Стосунки між жінками і чоловіками завжди були предметом уваги філософів, істориків, богословів, соціологів, культурологів, суспільних діячів. Нові світоглядні системи та поява гендерної теорії набувають поширення, а статева приналежність починає декларуватися предметом особистого вибору людини.

Автор розглядає поняття «гендер», виявляючи його соціокультурне значення та аналізуючи розвиток в історичній ретроспективі. Зазначається поліаспектність поняття «гендер» та варіативність акцентуацій у його тлумаченнях різними дослідниками. Розглядаючи історично гендерну проблематику, автор виділяє чотири статево-рольові типи, які притаманні як чоловікам, так і жінкам: мужній, жіночний, андрогенний і недиференційований.

Дослідження гендерної проблематики бере свій початок від античних мислителів, а саме: Платона та Аристотеля, які у своїх роботах започатковують розгляд питання взаємовідносин між чоловіком та жінкою як в межах родини, так і в суспільстві. Кожна історична епоха дає нам модель, за якою мають взаємодіяти чоловік та жінка. Епоха середньовіччя знаменується подвійним ставленням до гендерної проблематики: з одного боку, біблійна історія, а з іншого - середньовічне суспільство зі своїми нормами та уявленнями, де основні жіночі характеристики пов'язані з біологічним та культурним статусом жінки. У статті акцентовано увагу на тому, що одним із перших у вітчизняній ренесансній філософській думці, хто розглядав це питання, був Станіслав Оріховський. У працях суспільно-політичного та етичного спрямування він утверджував передовсім етику й ідеологію гуманізму, яка відводить особистості вищий щабель в ієрархії цінностей, висуває ідеал ії всебічного i гармонійного розвитку. Як ренесансний гуманіст, Оріховський вважав жінку благом не лише у приватному житті. Вона може бути, на його думку, корисною і для спільного блага держави, якщо $\epsilon$, наприклад, королевою.

Важливим є розуміння того, що гендерна проблематика носить історичний характер, який постійно знаходиться у процесі розвитку. Основною метою статті є розгляд еволюції формування гендерної проблематики в історико-філософському процесі.

Ключові слова: чоловік, жінка, рівність, гендер, сім'я, суспільство. 